\title{
Partial nail avulsion: habit or evidence based?
}

\author{
Priten Solanki ${ }^{*}$, Peta Craike ${ }^{2}$ \\ From Australasian Podiatry Council Conference 2011 \\ Melbourne, Australia. 26-29 April 2011
}

Onychocryptosis is a relatively common condition that can cause significant pain and discomfort. Partial nail avulsion (PNA) with phenolisation is a straightforward procedure performed by podiatrists on a daily basis. The procedure has shown a high rate of efficacy and low recurrence rate, and can be performed on high risk patients with close post-operative monitoring and those with concomitant infection. PNA with phenolisation of the nail matrix is a non-invasive procedure that does not require the use of an operating theatre and can be carried out in the podiatrist's rooms. Pre-operative measures do need to be taken, a local sterile field should be set up and the toe and forefoot should be scrubbed. Once the procedure has been completed healing can be expected in 4-8 weeks. The PNA procedure has been taught to undergraduate podiatrists since the late 1970's and has developed many small variations in how the procedure is carried out. Variations vary from preoperative management (type of antisepsis used), phenolisation time (reported to be between 1 to 5 minutes), type of post phenol irrigation (saline, isopropyl alcohol or no irrigation) and post-operative dressing regimen. These variations however are usually operator dependant and based on personal experience. Post-operative management of PNA wounds have attracted a lot of interest, with the use of different dressings (provodoneiodine impregnated gauze and paraffin gauze) and topical medicaments (manuka honey, intrasite gel) aimed at increasing the healing rate and reducing the rate of infection, but quantitative analysis of the colonisation of the wound bed shows a bacterial count of zero after the use of phenol. The case of the phenolised wound is an interesting one, an acute wound that heals by secondary intention and freely discharges for 2-4 weeks postoperatively. After the application phenol and the destruction

\footnotetext{
* Correspondence: priten.solanki@newcastle.edu.au

'Podiatry Lecturer, School of Health Sciences, University of Newcastle,

Ourimbah, NSW, 2258, Australia

Full list of author information is available at the end of the article
}

of all microbiological matter the post-operative focus should be in nurturing the recolonisation of the nail bed. Wounds that have a high as well as a low bacterial count have been shown to have an effect healing rates, but no studies have investigated the microbiological behaviour of a phenolised PNA wound.

\section{Author details}

${ }^{1}$ Podiatry Lecturer, School of Health Sciences, University of Newcastle, Ourimbah, NSW, 2258, Australia. ${ }^{2}$ Podiatry Lecturer, School of Health Sciences, University of Newcastle, Ourimbah, NSW, 2258, Australia.

Published: 20 May 2011

doi:10.1186/1757-1146-4-S1-046

Cite this article as: Solanki and Craike: Partial nail avulsion: habit or evidence based? Journal of Foot and Ankle Research 2011 4(Suppl 1):O46.

Submit your next manuscript to BioMed Central and take full advantage of:

- Convenient online submission

- Thorough peer review

- No space constraints or color figure charges

- Immediate publication on acceptance

- Inclusion in PubMed, CAS, Scopus and Google Scholar

- Research which is freely available for redistribution

Submit your manuscript at www.biomedcentral.com/submit
() Biomed Central
C Biomed Central

(c) 2011 Solanki and Craike; licensee BioMed Central Ltd. This is an open access article distributed under the terms of the Creative Commons Attribution License (http://creativecommons.org/licenses/by/2.0), which permits unrestricted use, distribution, and reproduction in any medium, provided the original work is properly cited. 